\title{
Analysis of the Strategic Emission-Based Energy Policies of Developing and Developed Economies with Twin Prediction Model
}

\author{
Yulian Jiang, ${ }^{1}$ Wuchang Wei, ${ }^{2}$ Ramesh Chandra Das $\mathbb{D}^{3},{ }^{3}$ and Tonmoy Chatterjee $\mathbb{D}^{4}$ \\ ${ }^{1}$ School of International Trade and Economics, Jiangxi University of Finance and Economics, Nanchang 330013, China \\ ${ }^{2}$ School of Architectural Engineering, Hezhou University, Hezhou 542899, China \\ ${ }^{3}$ Department of Economics, Vidyasagar University, Midnapore, WB, India \\ ${ }^{4}$ Department of Economics, Ananda Chandra College, Jalpaiguri, WB, India
}

Correspondence should be addressed to Ramesh Chandra Das; ramesh051073@gmail.com

Received 10 July 2020; Revised 2 October 2020; Accepted 28 October 2020; Published 11 November 2020

Academic Editor: Qingling Wang

Copyright (C) 2020 Yulian Jiang et al. This is an open access article distributed under the Creative Commons Attribution License, which permits unrestricted use, distribution, and reproduction in any medium, provided the original work is properly cited.

\begin{abstract}
Upholding sustainability in the use of energies for the increasing global industrial activity has been one of the priority agendas of the global leaders of the West and East. The projection of different GHGs has thus been the important policy agenda of the economies to justify the positions of their own as well as of others. Methane is one of the important components of GHGs, and its main sources of generation are the agriculture and livestock activities. Global diplomacy regarding the curtailment of the GHGs has set the target of reducing the levels of GHGs time to time, but the ground reality regarding the reduction is far away from the targets. Sometimes, the targets are fixed without the application of scientific methods. The aim of the present study is to examine sustainability of energy systems through the forecasting of the methane emission and agricultural output of the world's different income groups up to 2030 using the data for the period 1981-2012. The work is novel in two senses: the existing studies did not use both the Box-Jenkins and artificial neural network methods, and the present study covers all the major economic groups in the world which is unlike to any existing studies. Two methods are used for forecasting of the two. One is the Box-Jenkins method, where linear nature of the two variables is considered and the other is artificial neural network methods where nonlinear nature of the variables is also considered. The results show that, except the OECD group, all the remaining groups display increasing trends of methane emission, but unquestionably, all the groups display increasing trends of agricultural output, where middle- and upper middle-income groups hold the upper berths. The forecasted emission is justified to be sustainable in major groups under both methods of estimations since overall growth of agricultural output is greater than that of methane emission.
\end{abstract}

\section{Introduction}

From the last half of $19^{\text {th }}$ century to till date, economic growth turns into the most important particle of almost all socioeconomic systems in our mother earth. To achieve the higher growth trajectory, each and every economy put all of their resources on the board without giving any potentiality to future generations. It is only in late 90 s, when scarcity of resources and a relatively new term "global warming" knocking the door of the policy and law makers around the world, human beings push forward the agenda of sustainability. In the wake of the issues related to sustainability, researchers are often engaged themselves in a debate over the existence of whether substitutability or complementarity are working between the association of growth and environment $[1,2]$.

It has been historically evidenced that growth can revolutionize the structural changes in both production and consumption. Such changes may occur from either directions or both, that is, either from level or composition or from both of them [3]. Interestingly, both the level and the composition of production and consumption activities affect environmental degradation and raise the scope of greenhouse gas (GHG) emissions, owing to which the prospects 
of sustainable economic development may hamper in future $[4,5]$. It is evidenced that GHG contributes global warming and, consequently, generates severe environmental matters. It is to be noted that, to control the global emissions of GHG, the Kyoto Protocol was proposed and signed by almost all the countries in the world. The Kyoto Protocol specified six GHGs, including methane $\left(\mathrm{CH}_{4}\right)$, carbon dioxide $\left(\mathrm{CO}_{2}\right)$, nitrous oxide $\left(\mathrm{N}_{2} \mathrm{O}\right)$, perfluorocarbons (PFCS), hydrofluorocarbons (HFCS), and sulphur hexafluoride $\left(\mathrm{SF}_{6}\right)[6]$. In 2014, the concentration of carbon dioxide $\left(\mathrm{CO}_{2}\right)$, methane $\left(\mathrm{CH}_{4}\right)$, and nitrous oxide $\left(\mathrm{N}_{2} \mathrm{O}\right)$ in the atmosphere was $397.7 \mathrm{ppm}, 1833 \mathrm{ppb}$, and $325.9 \mathrm{ppb}$, respectively (World Meteorological Organization, 2015). On the average, the anthropogenic emissions grew $1.3 \%$ annually from 1970 to 2000 and $2.2 \%$ annually from 2000 to 2010 [7]. Moreover, after carbon dioxide, methane is the second most emitted GHG; its potential to catch heat in the atmosphere is 23 times higher than carbon dioxide [8] and so a clinical examination on increase in methane gas emission needs more attention.

Under 1996 IPCC revised guidelines, national GHG inventories includes energy, industrial process, solvent and other products, agriculture, land-use change and forestry, and waste, while the above-stated list is modified under 2006 IPCC guidelines $[6,9,10]$. Following the just-stated segregation of GHG, methane emissions are also generated from several production sectors. For instance, anthropogenic methane is emitted from sectors like cattle breeding, rice cultivation, extraction and transport of fossil fuels, and waste management [11]. These emissions result from very heterogeneous processes with several scopes for abatement. Accordingly, existing heterogeneity of production structures across countries introduces cross-country asymmetries broadly based on agriculture-based methane or industrybased methane emissions. Interestingly, methane emission and sectoral composition are rarely analyzed in the literature. However, such gap is widened enough in case of agricultural methane emissions. Methane is produced and emitted from the decomposition of livestock manure and the organic components in agro-industrial wastewater. These wastes are typically stored or treated in waste management systems that promote anaerobic conditions and produce biogas, a mixture of about 70 percent methane, 30 percent carbon dioxide, and less than 1 percent hydrogen sulfide. Globally, manure management added an approximated 237 million metric tons of carbon dioxide equivalent of methane emissions in 2010, roughly 4 percent of total anthropogenic methane emissions. Out of total emitted agro-based methane, almost 85 percent is accompanied by USA, China, and India together, followed by Brazil, Pakistan, and Vietnam [12]. It is to be noted that the agriculture methane may emit also from nations which use more capital-intensive production technique, and hence, a critical analysis between agriculture and methane emissions is needed abruptly.

Amalgamation of methane emission with agriculture production creates doubt over the efficacy of sustainability issue. Massive agriculture production can emit more vulnerable methane along with other GHGs. Again, such methane emissions may affect weather variability and multiply climate change risks and the magnitude of global warming. This can affect dairy cattle feeding sector along with other agriculture-based activities more severely. As a consequence, the vulnerability of agriculture-based livelihoods may increase with induced disaster risks. However, there is no definite and robust model which can estimate social costs from such emissions [13]. Hence, by minimizing environmental degradation and pollution risks along with adaptation to climate and weather, variability risks should not only increase resilience of farmers' production systems but also stabilize their output and income [14]. Identification and reduction of above-stated uncertainties and risk factors in terms of anticipatory adaptation may raise the potentiality of sustainability paradigm [15]. Therefore, climate change adaptation policies in the agricultural sector along with adaptation to control methane emission are to be implemented for getting sustainable development. Therefore, the question still remains in mind: "does complementarity between methane emission and agriculture production generate sustainability?" This paper also tries to locate, screen, and evaluate this issue for major income groups of the world.

This paper contributes original findings concerning methane emission and agriculture production with special emphasis on sustainability. First, it goes for forecasting of methane emission and agricultural output using the Box-Jenkins (BJ) and artificial neural network (ANN) methods. Second, it goes for testing the sustainability of methane emission vis-à-vis agricultural output.

The paper is organized as follows: literature review is presented first, followed by data, methodology, analysis of results, and conclusion.

\section{Literature Review}

Table 1 exhibits the brief information on the highly relevant works reviewed so far for the present study.

Analysis related to GHG emission and economic activities are not new in the literature. Study related to GHG emission and economic growth has been discussed in the literature quite rigorously [16-19]. All these studies used the similar kinds of methodology to relate GHG emission with growth. In fact, these studies have used $\mathrm{CO}_{2}$ as a measure of GHG and per capita income for panel data to show the presence of EKC. Again, there are a few studies that have used several GHGs, and they have confirmed the existence of EKC for methane emissions [20-22]. In this context, using a dataset for 22 OECD countries, it has shown a quadratic relationship between methane emission and GDP in the long run [20]. Such quadratic relationship between methane emission and GDP has also been established in the literature for different datasets [22]. Again, industrial methane emission of 39 countries explicitly claims $N$-shaped relationship between the methane emission and economic growth [21].

In a notable working series titled "OECD Environmental Outlook to 2030," it studies the prediction of GHG emissions in 2030 if the present inaction on environment remains unchanged [24]. The report reveals that, by 2030, the world economy is expected to nearly double and world population 
TABLE 1: List of relevant studies reviewed.

\begin{tabular}{|c|c|c|c|c|}
\hline Article & Year & Link with present study & Methodology & Outcomes \\
\hline $\begin{array}{l}\text { Acaravci and } \\
\text { Ozturk [16] }\end{array}$ & 2010 & $\begin{array}{l}\text { This study examines the causal } \\
\text { relationship between GHGs, energy } \\
\text { consumption, and economic growth }\end{array}$ & $\begin{array}{l}\text { Uses autoregressive distributed lag } \\
\text { (ARDL) bounds testing approach of } \\
\text { cointegration for nineteen European } \\
\text { countries }\end{array}$ & $\begin{array}{l}\text { Shows long-run relationship between } \\
\text { GHGs, energy consumption per } \\
\text { capita, real GDP per capita, and the } \\
\text { square of per capita real GDP }\end{array}$ \\
\hline $\begin{array}{l}\text { Apergis and } \\
\text { Ozturk [17] }\end{array}$ & 2015 & $\begin{array}{c}\text { This study focuses on both GDP and } \\
\text { policies in fourteen Asian countries } \\
\text { to capture income-emission } \\
\text { relationship }\end{array}$ & $\begin{array}{l}\text { Uses GMM method to a multivariate } \\
\text { panel data framework }\end{array}$ & $\begin{array}{l}\text { Illustrates inverted U-shaped } \\
\text { association between emissions and } \\
\text { per capita GDP for selected Asian } \\
\text { economies over the period } \\
\text { 1990-2011 }\end{array}$ \\
\hline $\begin{array}{l}\text { Coondoo and } \\
\text { Dinda [18] }\end{array}$ & 2002 & $\begin{array}{l}\text { This study presents the results of a } \\
\text { study of income and major GHG } \\
\text { emission }\end{array}$ & $\begin{array}{l}\text { Granger causality test is used to } \\
\text { cross-country panel data on per } \\
\text { capita income and the corresponding } \\
\text { per capita } \mathrm{CO}_{2} \text { emission }\end{array}$ & $\begin{array}{l}\text { For the group of developed } \\
\text { economies, the causality is found to } \\
\text { run from GHG emission in terms of } \\
\mathrm{CO}_{2} \text { emission to income }\end{array}$ \\
\hline
\end{tabular}

\begin{tabular}{|c|c|c|c|}
\hline & & & per capita $\mathrm{CO}_{2}$ emission \\
\hline $\begin{array}{l}\text { Kasman and } \\
\text { Duman [19] }\end{array}$ & 2015 & $\begin{array}{l}\text { This article examines the causal } \\
\text { relationship among energy } \\
\text { consumption, carbon dioxide } \\
\text { emissions, economic growth, trade } \\
\text { openness, and urbanization for a } \\
\text { panel of new EU member and } \\
\text { candidate countries }\end{array}$ & $\begin{array}{l}\text { Panel cointegration methods and } \\
\text { panel causality tests are used to } \\
\text { investigate such associations }\end{array}$ \\
\hline Cho et al. [20] & 2014 & $\begin{array}{l}\text { This study investigates the EKC } \\
\text { hypothesis by using the total GHG } \\
\text { and methane emission }\end{array}$ & $\begin{array}{c}\text { Uses panel cointegration tests as well } \\
\text { as the fully modified ordinary least } \\
\text { squares (FMOLS) approach }\end{array}$ \\
\hline $\begin{array}{l}\text { Fujii and } \\
\text { Managi }[21]\end{array}$ & 2016 & $\begin{array}{l}\text { This study analyzes the relationship } \\
\text { between economic growth and } \\
\text { emissions of major GHGs including } \\
\text { methane }\end{array}$ & $\begin{array}{l}\text { Uses of both time series and panel } \\
\text { data analysis }\end{array}$ \\
\hline
\end{tabular}

Short-run unidirectional panel causality running from energy consumption, trade openness, and urbanization to carbon emissions and long-run associations are claimed
This study investigates the EKC and methane emission

This study analyzes the relationship methane
Examines both EKC and $\mathrm{PHH}$ in the context of GHGs for Slovak Republic
Granger causality test
This study searches for the policy

Marchal et al. 2011 implications of the climate change [23] challenge in the context of methane emission and growth
Cross-sectional data and forecasting method are used

Employs simulations exercise in

This study predict the GHGs environmental conditions OECDEO [24] 2008 emissions in 2030 under unchanged order to find policy actions to address the key challenges, including their potential environmental, economic and social impacts

\begin{tabular}{|c|c|c|c|}
\hline $\begin{array}{l}\text { Ali and } \\
\text { Abdullah [25] }\end{array}$ & 2015 & $\begin{array}{l}\text { This study examines the association } \\
\text { between the major GHG emission } \\
\text { and its determinants like economic } \\
\text { growth, financial development, and } \\
\text { trade openness for the time period } \\
\text { 1970-2012 }\end{array}$ & $\begin{array}{l}\text { Uses vector error correction model } \\
\text { (VECM) approach to investigate the } \\
\text { relationship between the variables }\end{array}$ \\
\hline $\begin{array}{l}\text { Benavides } \\
\text { et al. [26] }\end{array}$ & 2017 & $\begin{array}{l}\text { This study investigates the } \\
\text { relationship between methane } \\
\text { emissions, GDP, electricity } \\
\text { production from renewable energy } \\
\text { sources, and trade openness }\end{array}$ & $\begin{array}{c}\text { Uses ARDL and Granger causality } \\
\text { test }\end{array}$ \\
\hline
\end{tabular}

Claims economic growth, financial development, and trade openness are still very important in determining the $\mathrm{CO}_{2}$ emissions Shows doubt over presence of EKC for several individual industries and illustrates the presence of EKC at the country and total industrial sector level data

Concludes that the volume of per capita per capita greenhouse gas emissions in the present period and in any of the previous four periods has no effect on the amount of net FDI inflows as a percentage of GDP in the Slovak Republic

Methane and nitrous oxide emissions are projected to increase to 2050 ;

although agricultural land is expected to expand slowly along with the escalation of agricultural productions in developing countries

Claims a rise in income and aspirations for better living standards will increase the pressure on the planet's natural resources 
TABle 1: Continued.

\begin{tabular}{|c|c|c|c|c|}
\hline Article & Year & Link with present study & Methodology & Outcomes \\
\hline Du et al. [27] & 2018 & $\begin{array}{l}\text { Illustrates methane emissions from } \\
2000 \text { to } 2014 \text { that originated from } \\
\text { wastewater from different provinces } \\
\text { in China }\end{array}$ & $\begin{array}{l}\text { Adopts artificial neural network } \\
\text { model }\end{array}$ & $\begin{array}{l}\text { Shows an increasing trend in } \\
\text { methane emissions in China and a } \\
\text { spatial transition of industrial } \\
\text { wastewater emissions }\end{array}$ \\
\hline $\begin{array}{l}\text { Fernández- } \\
\text { Amador et al. } \\
{[28]}\end{array}$ & 2018 & $\begin{array}{l}\text { Estimates the income elasticity of per } \\
\text { capita methane emissions }\end{array}$ & $\begin{array}{l}\text { Uses threshold models with } \\
\text { piecewise-linear income elasticity }\end{array}$ & $\begin{array}{c}\text { Income elasticity decreases at high } \\
\text { income levels but the rate is } \\
\text { diminishing }\end{array}$ \\
\hline $\begin{array}{l}\text { Shahbaz et al. } \\
\text { [29] }\end{array}$ & 2015 & $\begin{array}{l}\text { Examines the EKC hypothesis in } \\
\text { Portugal in the context of major } \\
\text { GHG emission }\end{array}$ & $\begin{array}{l}\text { Adopts ARDL bounds testing } \\
\text { approach }\end{array}$ & $\begin{array}{l}\text { Shows existence of EKC hypothesis } \\
\text { in both the short run and long run }\end{array}$ \\
\hline $\begin{array}{l}\text { Shahbaz et al. } \\
\text { [30] }\end{array}$ & 2014 & $\begin{array}{c}\text { Investigates the existence of EKC } \\
\text { hypotheses in case of Tunisia using } \\
\text { annual time series data for the period } \\
\text { of } 1971-2010\end{array}$ & $\begin{array}{l}\text { ARDL bounds testing approach, } \\
\text { vector error correction model, and } \\
\text { innovative accounting approach are } \\
\text { employed }\end{array}$ & $\begin{array}{l}\text { Claims long run association among } \\
\text { economic growth, energy } \\
\text { consumption, trade openness, and } \\
\mathrm{CO}_{2} \text { emissions }\end{array}$ \\
\hline Bates [31] & 2001 & $\begin{array}{l}\text { Considers agriculture GHG emission } \\
\text { with reference to methane and } \\
\text { nitrous oxide emissions in EU }\end{array}$ & $\begin{array}{l}\text { Time series and panel data analysis } \\
\text { are used }\end{array}$ & $\begin{array}{l}\text { Predicts that the baseline emissions } \\
\text { of methane and nitrous oxide in the } \\
\text { agricultural sector are likely to } \\
\text { decline by } 7 \%\end{array}$ \\
\hline $\begin{array}{l}\text { Fernández- } \\
\text { Amador et al. } \\
{[11]}\end{array}$ & 2018 & $\begin{array}{l}\text { Considers global dataset on methane } \\
\text { inventories derived from } \\
\text { production, final production, and } \\
\text { consumption for the time period } \\
\text { 1997-2011 }\end{array}$ & Uses panel data regression & $\begin{array}{l}\text { Shows the presence of relative } \\
\text { decoupling between methane and } \\
\text { growth, and the relationship is } \\
\text { nonlinear in nature }\end{array}$ \\
\hline $\begin{array}{l}\text { Hasegawa and } \\
\text { Matsuoka [32] }\end{array}$ & 2010 & $\begin{array}{l}\text { Introduces an integrated model to } \\
\text { predict global } \mathrm{CH}_{4} \text { and } \mathrm{N}_{2} \mathrm{O} \\
\text { emissions and reduction potentials } \\
\text { related to agricultural production } \\
\text { over the period } 2000 \text { to } 2030\end{array}$ & $\begin{array}{l}\text { Agricultural model and } \\
\text { countermeasure selection model are } \\
\text { introduced }\end{array}$ & $\begin{array}{l}\text { Claims that the livestock manure } \\
\text { management and rice paddy are } \\
\text { expected to be emission sources that } \\
\text { have high reduction potentials }\end{array}$ \\
\hline $\begin{array}{l}\text { Adger et al. } \\
\text { [33] }\end{array}$ & 2005 & $\begin{array}{l}\text { This study reviews the nature of } \\
\text { adaptation and also examines the } \\
\text { implications of different spatial } \\
\text { scales for these processes }\end{array}$ & Uses normative evaluative criteria & $\begin{array}{l}\text { Shows that elements of effectiveness, } \\
\text { efficiency, equity, and authenticity } \\
\text { are important in claiming success in } \\
\text { terms of the sustainability }\end{array}$ \\
\hline $\begin{array}{l}\text { Asghar et al. } \\
\text { [34] }\end{array}$ & 2006 & $\begin{array}{l}\text { Introduces the ideas of disasters } \\
\text { management with GHG emission }\end{array}$ & $\begin{array}{l}\text { Model of integrated disaster } \\
\text { management is used }\end{array}$ & $\begin{array}{c}\text { Findings have claimed that proper } \\
\text { policy investigations, plans, } \\
\text { programmes and adaptation in terms } \\
\text { of risks, and opportunities can make } \\
\text { GHG emissions as sustainability } \\
\text { indicators }\end{array}$ \\
\hline $\begin{array}{l}\text { Barnett and } \\
\text { O’Neill [35] }\end{array}$ & 2010 & $\begin{array}{l}\text { Relates adaptation and GHGs in the } \\
\text { context of Melbourne }\end{array}$ & Considers comparative analysis & $\begin{array}{l}\text { Claims in favour of introduction a } \\
\text { line of investigation that the policy- } \\
\text { makers should ask and seek answers } \\
\text { before committing resources to } \\
\text { adaptation decisions }\end{array}$ \\
\hline Haddad [14] & 2005 & Relates HDI with GHGs & Introduces sociopolitical model & $\begin{array}{c}\text { Advocates that adaptive capacity } \\
\text { based on national sociopolitical } \\
\text { aspirations is needed }\end{array}$ \\
\hline $\begin{array}{l}\text { Maredia and } \\
\text { Minde [36] }\end{array}$ & 2002 & $\begin{array}{l}\text { Examines association among } \\
\text { agriculture, technology, and } \\
\text { environmental degradation }\end{array}$ & $\begin{array}{l}\text { Uses Africa-based analysis with } \\
\text { descriptive statistics }\end{array}$ & $\begin{array}{c}\text { Finds lack of adaptation may degrade } \\
\text { environment with more higher } \\
\text { agricultural productivity in Africa }\end{array}$ \\
\hline $\begin{array}{l}\text { Mimura et al. } \\
\text { [37] }\end{array}$ & 2014 & $\begin{array}{c}\text { Relates adaptation with climate } \\
\text { change }\end{array}$ & Adaptation strategy is employed & $\begin{array}{l}\text { Recognizing the importance of } \\
\text { mainstreaming adaptation and the } \\
\text { integration of adaptation policies } \\
\text { within those of development } \\
\text { increases }\end{array}$ \\
\hline Volenzo [38] & 2015 & $\begin{array}{l}\text { Relates methane emission, } \\
\text { agriculture, and adaptation }\end{array}$ & $\begin{array}{l}\text { Simulation exercises has been } \\
\text { introduced }\end{array}$ & $\begin{array}{l}\text { Claims failure to adopt proper } \\
\text { adaptation may aggravate small-scale } \\
\text { farmers' vulnerability to climate } \\
\text { change and weather variability and in } \\
\text { return economy will produce } \\
\text { suboptimal outcomes }\end{array}$ \\
\hline
\end{tabular}


TABLE 1: Continued.

\begin{tabular}{lcccc}
\hline Article & Year & Link with present study & Methodology & Outcomes \\
\hline $\begin{array}{l}\text { Volenzo et al. } 2019 \\
{[39]}\end{array}$ & $\begin{array}{c}\text { Related to methane emission, } \\
\text { agriculture, and adaptation }\end{array}$ & $\begin{array}{c}\text { Encouraged to design and implement } \\
\text { policies and strategies that take } \\
\text { cognizance of poverty- } \\
\text { maladaptation-environmental } \\
\text { degradation nexus }\end{array}$ \\
\hline
\end{tabular}

to grow from 6.5 billion today to over 8.2 billion. Most of the growths in income and population will be in the emerging economies of Brazil, Russia, India, Indonesia, China, and South Africa (the BRIICS) and in other developing countries. Rising income and aspirations for better living standards will increase the pressure on the planet's natural resources. In another series titled "OECD Environmental Outlook to 2050," it envisages that, without more ambitious policies than those in force today, GHG emissions will increase by another $50 \%$ by 2050 , primarily driven by a projected $70 \%$ growth in $\mathrm{CO}_{2}$ emissions from energy use [23]. This is primarily due to a projected $80 \%$ increase in global energy demand. Furthermore, it claims that, historically, although OECD economies have been responsible for most of the emissions, in the coming decades, increasing emissions will also be caused by high economic growth in some of the major emerging economies. Again, global energy-related carbon dioxide $\left(\mathrm{CO}_{2}\right)$ emissions are projected to increase by one-third between 2012 and 2040. The continuing increase in total emissions occurs despite a moderate decrease in the carbon intensity $\left(\mathrm{CO}_{2}\right.$ per unit of energy) of the global energy supply [40].

From the international trade angle, a few studies have found positive relationship between trade openness and $\mathrm{CO}_{2}$ emissions $[25,29,30]$. Positive association between methane emission and trade openness is also acknowledged in the literature [26]. Moreover, economic growth and several socioeconomic activities are claimed responsible for methane emission [25]. In fact, rapid growth, population size, and foreign direct investment are made as the responsible factors behind methane emission for different cross-sections [30]. Again, through an interesting study, it is reported that the elasticity of methane emissions with respect to income per capita income is low and it may decrease over time [28]. In a recent study based on country specific efforts, it has been calculated by neural network method that the predicted methane emission from wastewater in China will be an increasing trend and a spatial transition of industrial wastewater emissions from eastern and southern regions to central and southwestern regions and from coastal regions to inland regions will occur [27].

Again, some studies are focused on the reduction potentiality of methane emission from agriculture [31, 41]. Usually, such studies have used static methodology and derived short-run estimates to locate the reduction possibility of methane emission from agricultural sector [31, 41]. However, long-run analysis has also been established, in which methane emissions from agriculture and reduction prospective under several marginal abatement costs, huge drop likely regions, and emission sources are claimed for long-run [32]. Again, establishing the significance of agricultural sector in the context of GHGs emission, it has been claimed that the anthropogenic methane emissions are mostly produced by a few economic sectors such as cattle breeding and rice cultivation [11].

Issues related to sustainable development in the context of agriculture production and methane gas emission have been discussed critically in the literature. Furthermore, it is argued that proper policy investigations, plans, programmes, and adaptation in terms of risks and opportunities can make GHG emissions as sustainability indicators to uphold sustainable development $[34,42]$. To get sustainability, investigators are usually advocated for the attractive adaptation measures to pursue efficiently in long run [37]. Investigation in this aspect has revealed that, by controlling environmental degradation and pollution risks along with adaptation to climate and weather, variability risks may increase resilience of farmers' production systems and also side by side stabilize their output and income [14]. In another series titled "Sendai framework for disaster risk reduction 2015-2030," it has been argued that minimization of uncertainties and risk factors owing to climate change attached to agriculture can be optimized through anticipatory adaptation [15]. Sustainable development in terms of improvement of farmer's livelihood is claimed and argued in favour of proper adaptation of changing policy regimes in the context of environmental degradation to opt sustainability [36]. Again, with inability to screen, evaluate, and treat risks augmented in dairy feeding, adaptation initiatives are declared as responsible factors to enhance risks embedded in climate change. Furthermore, studies claim that just-stated failure to adopt proper adaptation may aggravate small-scale farmers' vulnerability to climate change and weather variability, and in return, economy will produce suboptimal outcomes $[33,35,38]$. In a more recent study, it has been claimed that methane gas emission along with other GHGs emissions from agriculture production and in dairy feeding strategies can be used as a measure and indicator of sustainability. It has been further argued that policy implementation to curb risks associated with agriculture production owing to methane emission must be embedded with the cognizance of poverty, maladaptation, and environmental degradation nexus [39].

\section{Rationale of the Present Study}

The review of literature highlights different aspects of GHG emission in general and methane emission in particular and their impacts in different sectors of different economies but does not cover studies related to forecasting of methane 
emission in world's leading methane emitting countries. The present study has tried to fill the gap in the literature by means of forecasting methane emission for world's leading economic groups up to the year 2030. Furthermore, the sustainability of the forecast values of methane emission has been analyzed by means of forecast values of agricultural output of the same economic groups. It is thus a novel work in our view.

3.1. Data. The study uses the time series data on methane emission (in $\mathrm{kt} \mathrm{CO}_{2}$ equivalent) for the five groups of economies (high income, upper middle income, middle income, lower middle income, and low income) for the period 1981-2012. It also uses the time series data for the same period and same groups of economies on the total agricultural value added measured in current USD. Both the data series are borrowed from the World Bank (http://www. wordbank.org).

3.2. Methodology. Twin methods, not actually hybrid in usual sense, are used for forecasting of methane emission and agricultural value added. One is the Box-Jenkins method, where linear nature of the two variables is considered, and the other is artificial neural network methods, where nonlinear nature of the variables is also considered.

3.3. Box-Jenkins Method of Forecasting. Before going into the details of Box and Jenkins method of forecasting, we need to see how a time series data of a particular variable is generated.

There are three processes behind generation of a time series data:

(1) AR process: past values of the variable and error term generate the data

(2) MA process: only the errors or the disturbance term generate the data

(3) ARMA process: data are generated by the combination of $\mathrm{AR}$ and MA processes

Sometimes, it is taken as ARIMA model, where " $I$ " stands for integration of the series or how many differencing is done for making the time series of the variable to stationary.

In the AR $(p)$ process, the current value of a variable " $y$ " depends on only the past values plus an error term. If there are " $p$ order in the process, i.e., the current value of $y$ depends on the $p$ order of past values and an error term of the current period," then the $\operatorname{AR}(p)$ can be written as

$$
\begin{aligned}
y_{t}= & \mu+\varphi_{1} y_{t-1}+\varphi_{2} y_{t-2}+\varphi_{3} y_{t-3}+\varphi_{4} y_{t-4} \\
& +\cdots+\varphi_{p} y_{t-p}+u_{t}=\mu+\sum \varphi_{i} y_{t-i}+u_{t},
\end{aligned}
$$

where $u_{t}$ is the white noise ( $\mathrm{WN}$ ) error term with zero mean, constant variance, and zero auto-covariance.

On the contrary, an $\operatorname{MA}(q)$ process is the linear combination of all the " $q$ " terms of white noise terms depending on time. It is a white noise process in which the current value of $y_{t}$ depends on the current value of the WN error term and all past values of the error terms. Because all the errors are $\mathrm{WN}$, an MA process is necessarily a stationary process further because it is the linear combination of all plus and minus values of the errors which hover around zero.

So, an MA $(q)$ process can be written as

$$
\begin{aligned}
y_{t} & =u_{t}+\theta_{1} u_{t-1}+\theta_{2} u_{t-2}+\theta_{3} u_{t-3}+\theta_{4} u_{t-4}+\cdots+\theta_{q} u_{t-q} \\
& =u_{t}+\sum \theta_{i} u_{t-i} .
\end{aligned}
$$

An AR process is stationary if the characteristic root lies outside the unit circle or having values $>1$, then $\varphi$ becomes less than 1 . This means the condition $\varphi<1$ leads to the values lying inside the unit circle representing stationarity of the AR process, and the model will thus have stability property.

An ARIMA $(p, q)$ process is the combination of AR and MA processes, " $I$ " being the order of integration, which can be represented by " $d$," number of differencing to convert the series from nonstationary to stationary. The model for $\operatorname{ARMA}(p, d, q)$ can then be written as

$$
\begin{aligned}
y_{t}= & \mu+\varphi_{1} y_{t-1}+\varphi_{2} y_{t-2}+\varphi_{3} y_{t-3}+\varphi_{4} y_{t-4}+\cdots+\varphi_{p} y_{t-p} \\
& +u_{t}+\theta_{1} u_{t-1}+\theta_{2} u_{t-2}+\theta_{3} u_{t-3}+\theta_{4} u_{t-4}+\cdots+\theta_{q} u_{t-q} .
\end{aligned}
$$

Using Lag operator, we have

$$
\begin{aligned}
\left(1-\varphi_{1} L-\varphi_{2} L^{2}-\varphi_{3} L^{3}-\varphi_{4} L^{4}-\cdots-\varphi_{p} L^{p}\right) y_{t} & =\mu+\left(1+\theta_{1} L+\theta_{2} L^{2}+\theta_{3} L^{3}+\theta_{4} L^{4}+\cdots+\theta_{q} L^{q}\right) u_{t} O r, \\
\varphi(L) y_{t} & =\mu+\theta(L) u_{t} .
\end{aligned}
$$

This relation stands for invertibility between the AR and the MA process.

3.4. Forecasting in ARIMA Model: Box-Jenkins Method. The BJ methodology to determine which model is appropriate follows a four-step procedure:
Step 1: identification: to determine the appropriate values of $p, d$, and $q$.

(i) The main tools in this search are the correlogram and partial correlogram.

Step 2: estimation: to estimate the parameters of the chosen model. 
Step 3: diagnostic checking: to check if the residuals from the fitted model are white noise.

(i) If they are, accept the chosen model; if not, start afresh.

(ii) That is why the $\mathrm{BJ}$ methodology is an iterative process.

Step 4: forecasting. The ultimate test of a successful ARIMA model lies in its forecasting performance, within the sample period as well as outside the sample period. On the basis of the acceptable results obtained from steps 1 to 3 , forecasting is made on the appropriate model of ARIMA. The forecasting results are accepted on the basis of the acceptable values of root mean square error (RMSE), bias proportion, variance proportions, and covariance proportions. The acceptable forecasted values will be those whose RMSE will be minimum possible, and covariance proportions will be greater than bias proportions and variance proportions.

\section{Methodology of ANN-Based NAR}

Real-world data always contains nonlinearity, and specifically, its behaviour is dynamic and depends on their current period. Under such circumstances, the nonlinear autoregressive (NAR) neural network structure is effective to make efficient prediction about future [43]. The first advantage of NAR networks is that they can accept dynamic inputs represented by time series sets. Time series forecasting using a neural network is a nonparametric method, which implies that knowledge of the process that causes the time series is not necessary. Moreover, the NAR model utilizes the past values of the time series to predict future values. This fact makes it hard to model time series using a linear model; therefore, a nonlinear approach should be preferred, and the present study has also attempted the method. A nonlinear autoregressive neural network, applied to time series forecasting, describes a discrete, nonlinear, autoregressive model that can be expressed in the following manner [44, 45]:

$$
x(t)=f(x(t-1), x(t-2), x(t-3), \ldots \ldots, x(t-q))+v(t),
$$

where $x(t)$ is data series of $x$ variable at time $t ; f($.$) is$ unknown in advance, and the training of the neural network aims to approximate the function by means of the optimization of the network weights and neuron bias; and $v(t)$ is the error of the approximation of $x$ at time $t$.

This training function is often operated efficiently with backpropagation-type algorithm, and to perform this with our stated $f($.$) , we use Levenberg-Marquardt back-$ propagation procedure (LMBP) $[46,47]$ to solve any specified NAR neural network. In Figure 1, we present the topology of a standard NAR network.

After getting the forecasted values of both the series for methane emission and agricultural value added up to the year 2030, we try to test whether the forecasted methane emission is sustainable by means of looking at the forecasted values in agricultural outputs for the selected five groups of economies. For this purpose, we have first calculated the growth of these two indicators over the forecast period and average values of these two growth rates for all the groups. After that, we have tested the mean difference of these two indicators, methane emission and agricultural value added, and tested their significance statistically. If the average growth of agricultural output is tested to be greater than that of methane emission, then it may be said that the emission is sustainable as it contributes positively and largely to agricultural output. The reverse results may say the unsustainable methane emission in the forecasted period.

4.1. Analysis of Results. As mentioned earlier, the study applies Box-Jenkins (BJ) and artificial neural network (ANN) for forecasting methane emission and agriculture output for the period 2013-2030 on the basis of data for the period 1981-2012. The results of both the methods are given one by one.

4.1.1. Forecasting by Box-Jenkins Method. For the BJ method, the following four steps are followed which are mentioned in Methodology:

Step 1: identification: to determine the appropriate values of $p, d$, and $q$, we have done unit root test through ADF test and correlogram methods. The results for both the series are presented in Tables 2 and 3 . Looking at the autocorrelation functions (ACFs) and partial autocorrelation functions (PACFs), we have identified the orders of $\mathrm{AR}$ and MA processes. There may be more than one alternative of the shapes of ACF and PACF, and we will have to determine the optimum structure of ARIMA. For this purpose, steps 2 and 3 are followed.

Step 2: estimation: to estimate the parameters of the chosen model, we run equation (4).

Step 3: diagnostic checking: to check if the residuals from the fitted model are white noise. The acceptable regression results are taken on the basis of where both $\mathrm{AR}$ and MA coefficients are significant, adjusted $R^{2}$ is highest, and information criteria (AIC and SIC) are of lowest values. The results of steps 1 to 3 are given in Table 2 for methane emission and in Table 2 for agriculture output for all the groups of economies. The roots of the AR and MA should lie inside the unit circle, indicating stability of the models.

Let us first discuss the results (for steps 1 to 3 ) on the methane emission with the help of Table 2. The results from the table show that, in all the groups of economies, the series are integrated of order 1 . The optimum orders of the autoregressive and moving average terms are marked bold. They are $(4,4)$ for the OECD and lower middle group, $(11,11)$ for the upper middle group, $(6$, $6)$ for the middle group, and $(1,1)$ for the low group. And all of these terms are less than unity in values, indicating the stability of the models. 


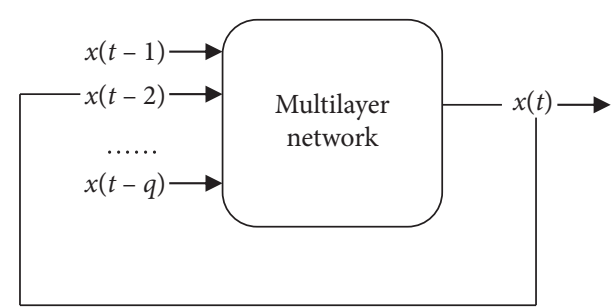

FIGURE 1: Nonlinear autoregressive neural network.

Now come to the discussion on the results (for steps 1 to 3 ) of agriculture output with the help of Table 3 . The results from the table show that, in all the groups of economies, the series are integrated of order 1. The optimum orders of the AR and MA terms are marked bold. They are $(2,12)$ for the OECD group, $(4,1)$ for the upper middle group, $(3,1)$ for the middle group, $(3,3)$ for the lower middle group, and $(1,1)$ for the low group. And the models in all the groups are stable.

Step 4: forecasting: on the basis of the acceptable results obtained from steps 1 to 3 , forecasting is made on the appropriate model of ARIMA. The forecasting results are accepted on the basis of the acceptable values of root mean square error (RMSE), bias proportion, variance proportions, and covariance proportions. Figures 2 and 3 present the graphical plots of forecasted values of methane emission and agricultural output, respectively. The numerical values of the two forecasted series are given in the Appendix (Tables 4 and 5).

It is observed from Figure 2 that, except the OECD group, all the remaining four groups of economies demonstrate rising trends of forecasted values of methane emission. Middle-income group leads the club followed by the upper middle-income group and low-income group. The lower middle-income group maintains a constant forecasted path for the entire period of prediction. The positive improvements are observed only for the countries in the OECD group. The results thus show that the agriculture activity in particular and all the economic activity in general is not going to put pressure on the pollution level measured by methane emission for the developed countries, whereas the countries in the remaining world are going to pollute the environment. The derived forecasted values of methane emission have maintained the desirable properties of forecasting as their RMSE is low and the covariance proportions are greater than the bias and variance proportions (the results are not shown to avoid crowding of figures and tables in the text).

On the contrary, the forecasted values of agricultural value added for all the groups under the BJ method, as depicted in Figure 3 and Table 5, show rising trends for all up to 2030. But the difference is observed in their relative positions. The middle-income group is at the top, followed by the upper middle-, lower middle-, OECD, and low-income group. The rate of growth is steeper for the middle-income group as well.

4.1.2. Forecasting by ANN-Based NAR. In the ANN method, only one hidden layer has been used while number of neurons in hidden layer has been varied at four levels $(5,10$, 15 , and 20 number of neurons). Our experiments suggest employing 2 feedback delays of the variables for model building. Here, we have used backpropagation algorithm proposed by Levenberg-Marquardt for training. Figures 4 and 5, respectively, present the predicted values of methane emission and agriculture output. The quantitative figures for both are presented in the Appendix (Tables 6 and 7).

It is observed from Figure 4 that the OECD group demonstrates falling trend of the predicted methane emission, while the other four groups from low- to upper middle-income countries produce rising trends of the said emission. Furthermore, it is to note that the results under the ANN method are similar to that under the BJ method.

Figure 5 depicts that all the groups' predicted trends of agriculture output are upward rising over time which are alike to that under BJ method. But a little difference under ANN is observed for the OECD group as it turned downward trend after 2015.

Hence, the two methods of forecasting by and large produce the same results for both methane emission and agricultural output for all the groups of economies. Whatever differences observed are due to the differences in methodological structures. As mentioned in related literature [48-50] that the ANN is applied for linear and nonlinear data and BJ only for linear data, the former one can be used as better predictor for a dynamic variable like methane emission. As having association between methane emission and agricultural output, it is now required to examine whether the predicted methane emission is sustainable for all the groups for the period 2013-2030. This is the second objective of the study.

One way of examining such sustainability is to see whether growth of the predicted agricultural output is greater than that of methane emission. In other words, whether good economic effect is greater than bad pollution effect. For the said purpose, we have calculated the average growth rates of predicted methane emission and agricultural output and took their difference and test statistically (by $t$ test) whether such mean difference is positive statistically. We have done these tests for all the groups of economies separately for $\mathrm{BJ}$ and $\mathrm{ANN}$ results. The test results are given in Table 8.

It is observed from both the two methods of forecasting that the average growth for predicted methane emission is negative for the OECD group and positive for all the remaining four groups. Furthermore, the average growth of agricultural output is greater than that of the methane emission for all the groups of economies. The correlation between the growth of methane emission and that of agriculture output is positive and significant for all in case of the BJ method, but the correlation result is not significant for all the groups in case of the ANN method.

The results for mean difference test are positive and significant under the BJ method for all the groups which mean that the forecasted values of agriculture output are significantly greater than that of methane emission. This 
TABLE 2: Unit root test and ARIMA results for methane emission.

\begin{tabular}{|c|c|c|c|c|c|c|}
\hline Groups & $\mathrm{ADF}$ & Possible forms of ARIMA & Regression coefficients (prob) & $\overline{\mathrm{R}}^{2}$ & AIC & SIC \\
\hline \multirow{3}{*}{$26 \mathrm{OECD}$} & \multirow{3}{*}{$-5.83(0.00)$} & $(2,1,2)$ & $\operatorname{AR}(2)=-0.67(0.00) \mathrm{MA}(2)=0.71(0.05)$ & 0.14 & 21.79 & 21.83 \\
\hline & & $(4,1,4)$ & $\operatorname{AR}(4)=0.50(0.00) \mathrm{MA}(4)=-0.91(0.02)$ & 0.27 & 21.5 & 21.65 \\
\hline & & $(11,1,11)$ & $\mathrm{AR}(11)=-0.17(0.23) \mathrm{MA}(11)=0.87(0.05)$ & 0.62 & 20.6 & 20.75 \\
\hline \multirow{2}{*}{ Upper middle income } & \multirow{2}{*}{$-4.11(0.00)$} & $(3,1,4)$ & $\mathrm{AR}(3)=0.39(0.02) \mathrm{MA}(4)=-0.24(0.22)$ & 0.07 & 25.05 & 25.19 \\
\hline & & $(11,1,11)$ & $\operatorname{AR}(11)=-0.8(0.01) \mathrm{MA}(11)=-0.94(0.00)$ & 0.91 & 22.84 & 22.99 \\
\hline \multirow{3}{*}{ Middle income } & \multirow{3}{*}{$-8.15(0.00)$} & $(1,1,6)$ & $\mathrm{AR}(1)=-0.18(0.35) \mathrm{MA}(6)=-0.16(0.42)$ & 0.001 & 27.33 & 27.47 \\
\hline & & $(6,1,6)$ & $\operatorname{AR}(6)=-0.57(0.00) \mathrm{MA}(6)=0.96(0.00)$ & 0.38 & 26.96 & 27.11 \\
\hline & & $(15,1,15)$ & $\operatorname{AR}(15)=0.01(0.48) \mathrm{MA}(15)=-0.99(0.02)$ & 0.99 & 7.64 & 7.78 \\
\hline \multirow{3}{*}{ Lower middle income } & \multirow{3}{*}{$-8.5(0.00)$} & $(1,1,4)$ & $\operatorname{AR}(1)=-0.38(0.00) \mathrm{MA}(4)=-0.08(0.24)$ & 0.12 & 27.31 & 27.45 \\
\hline & & $(4,1,4)$ & $\operatorname{AR}(4)=0.6(0.02) \mathrm{MA}(4)=-0.94(0.01)$ & 0.15 & 27.30 & 27.42 \\
\hline & & $(15,1,4)$ & $\mathrm{AR}(15)=0.15(0.16) \mathrm{MA}(4)=-0.94(0.01)$ & 0.77 & 26.48 & 26.49 \\
\hline \multirow{2}{*}{ Low income } & \multirow{2}{*}{$-7.37(0.00)$} & & $\operatorname{AR}(1)=0.45(0.00) \mathrm{MA}(1)=-0.99(0.01)$ & 0.24 & 24.68 & 24.82 \\
\hline & & $(1,1,4)$ & $\mathrm{AR}(1)=-0.31(0.28) \mathrm{MA}(4)=-0.17(0.21)$ & 0.05 & 24.89 & 25.03 \\
\hline
\end{tabular}

Note. Bold marks indicate significant results and the accepted ARIMA structures for which forecasting is made. Source: computed by the authors.

TABLE 3: Unit root test and ARIMA results for agricultural value addition.

\begin{tabular}{|c|c|c|c|c|c|c|}
\hline Groups & $\mathrm{ADF}$ & Possible forms of ARIMA & Regression coefficients (prob) & $R^{2}$ & AIC & SIC \\
\hline $26 \mathrm{OECD}$ & $-5.81(0.00)$ & $\begin{array}{l}(2,1,2) \\
(2,1,12) \\
(13,1,12)\end{array}$ & $\begin{array}{c}\mathrm{AR}(2)=0.18(0.36) \mathrm{MA}(2)=-0.99(0.04) \\
\operatorname{AR}(2)=-\mathbf{0 . 4 7}(\mathbf{0 . 0 0 )} \mathrm{MA}(\mathbf{1 2})=-\mathbf{0 . 8 9}(\mathbf{0 . 0 2}) \\
\mathrm{AR}(13)=-0.62(0.00) \mathrm{MA}(12)=-0.88(0.05)\end{array}$ & $\begin{array}{l}0.33 \\
0.65 \\
0.70\end{array}$ & $\begin{array}{l}51.48 \\
50.81 \\
50.85\end{array}$ & $\begin{array}{l}51.62 \\
50.95 \\
51.01\end{array}$ \\
\hline Upper middle income & $-4.11(0.00)$ & $\begin{array}{l}(1,1,1) \\
(1,1,3) \\
(3,1,1) \\
(3,1,3) \\
(4,1,1) \\
(4,1,3)\end{array}$ & $\begin{array}{l}\operatorname{AR}(1)=0.95(0.02) \mathrm{MA}(1)=-0.66(0.00) \\
\operatorname{AR}(1)=0.47(0.03) \mathrm{MA}(3)=0.39(0.01) \\
\operatorname{AR}(3)=0.71(0.00) \mathrm{MA}(1)=0.31(0.22) \\
\operatorname{AR}(3)=0.78(0.32) \mathrm{MA}(3)=-0.06(0.22) \\
\operatorname{AR}(4)=\mathbf{0 . 6 7}(\mathbf{0 . 0 1}) \mathrm{MA}(\mathbf{1})=\mathbf{0 . 5 7}(\mathbf{0 . 0 0 )}) \\
\operatorname{AR}(4)=0.52(0.01) \mathrm{MA}(3)=0.33(0.20)\end{array}$ & $\begin{array}{l}0.33 \\
0.34 \\
0.38 \\
0.34 \\
0.36 \\
0.29\end{array}$ & $\begin{array}{c}52.26 \\
52.25 \\
52.24 \\
52.4 \\
52.24 \\
52.41\end{array}$ & $\begin{array}{r}52.4 \\
52.39 \\
52.38 \\
52.54 \\
52.38 \\
52.56\end{array}$ \\
\hline Middle income & $-8.15(0.00)$ & $\begin{array}{l}(1,1,1) \\
(3,1,1) \\
(3,1,3)\end{array}$ & $\begin{array}{l}\operatorname{AR}(1)=0.98(0.02) \mathrm{MA}(1)=-0.68(0.00) \\
\operatorname{AR}(3)=\mathbf{0 . 8 0}(\mathbf{0 . 0 0}) \mathbf{M A}(\mathbf{1})=\mathbf{0 . 3 7}(\mathbf{0 . 0 0}) \\
\operatorname{AR}(3)=0.93(0.04) \mathrm{MA}(3)=-0.08(0.22)\end{array}$ & $\begin{array}{l}0.40 \\
0.48 \\
0.45\end{array}$ & $\begin{array}{l}52.96 \\
52.87 \\
52.93\end{array}$ & $\begin{array}{c}53.1 \\
53.01 \\
53.00 \\
\end{array}$ \\
\hline Lower middle income & $-8.5(0.00)$ & $\begin{array}{l}(1,1,1) \\
(3,1,1) \\
(3,1,3)\end{array}$ & $\begin{array}{c}\mathrm{AR}(1)=0.91(0.02) \mathrm{MA}(1)=-0.58(0.24) \\
\mathrm{AR}(3)=0.82(0.00) \mathrm{MA}(1)=0.29(0.38) \\
\operatorname{AR}(\mathbf{3})=\mathbf{0 . 6 1}(\mathbf{0 . 0 4}) \mathrm{MA}(\mathbf{3})=\mathbf{0 . 4 6}(\mathbf{0 . 0 2})\end{array}$ & $\begin{array}{l}0.35 \\
0.45 \\
0.46\end{array}$ & $\begin{array}{l}51.09 \\
50.96 \\
50.94\end{array}$ & $\begin{array}{l}51.23 \\
51.10 \\
51.08\end{array}$ \\
\hline Low income & $-7.37(0.00)$ & $\begin{array}{l}(1,1,1) \\
(2,1,1) \\
(3,1,1) \\
(4,1,1)\end{array}$ & $\begin{array}{c}\operatorname{AR}(\mathbf{1})=\mathbf{0 . 9 5}(\mathbf{0 . 0 0}) \mathrm{MA}(\mathbf{1})=-\mathbf{0 . 6 7}(\mathbf{0 . 0 1}) \\
\operatorname{AR}(2)=0.36(0.28) \mathrm{MA}(1)=0.4(0.01) \\
\operatorname{AR}(3)=0.9(0.38) \mathrm{MA}(1)=0.18(0.31) \\
\operatorname{AR}(4)=0.35(0.28) \mathrm{MA}(1)=0.19(0.21)\end{array}$ & $\begin{array}{l}0.30 \\
0.16 \\
0.16 \\
0.14\end{array}$ & $\begin{array}{c}47.3 \\
47.5 \\
47.5 \\
47.57\end{array}$ & $\begin{array}{l}47.44 \\
47.64 \\
47.64 \\
47.61\end{array}$ \\
\hline
\end{tabular}

Note. Bold marks indicate significant results and the accepted ARIMA structures for which forecasting is made. Source: computed by the authors.

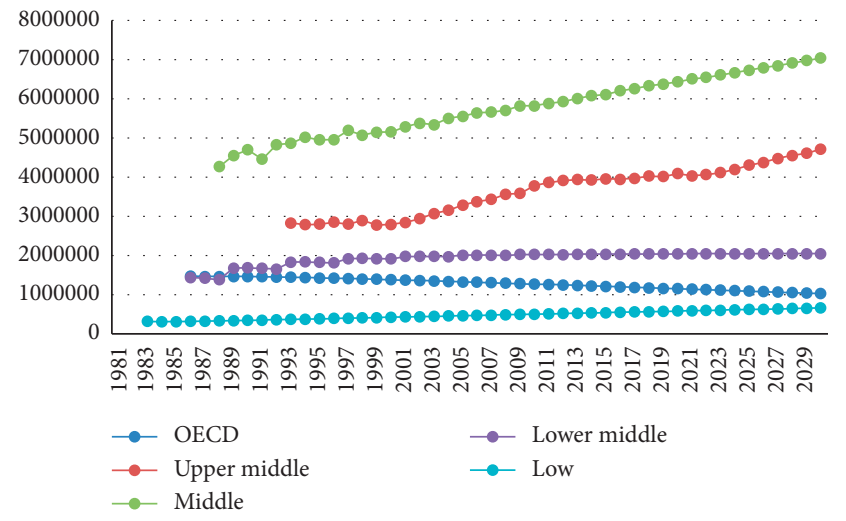

FIGURE 2: Forecasted values of methane emission (in kt of equivalent $\mathrm{CO}_{2}$ ) under the $\mathrm{BJ}$ method. Source: drawn by the authors.

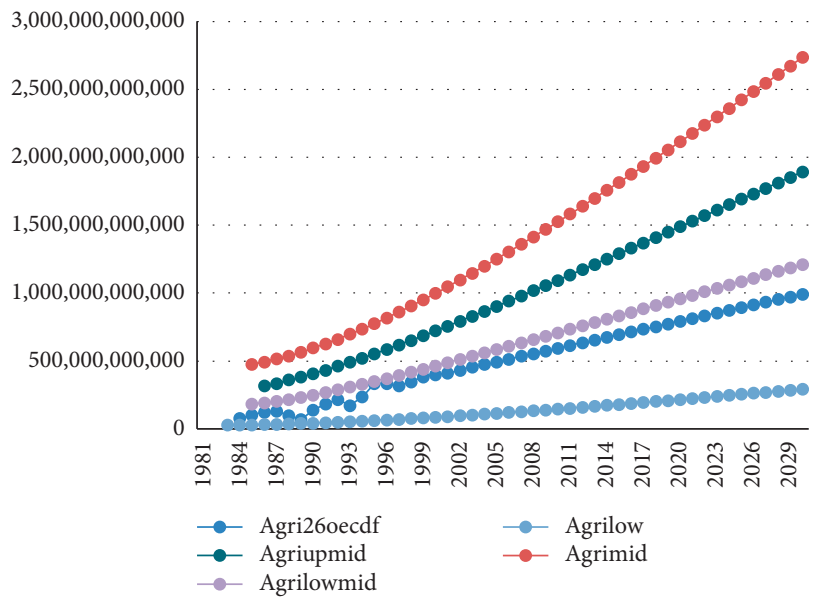

FIGURE 3: Forecasted values of agriculture output (in current USD) by the BJ method. Source: drawn by the authors. 


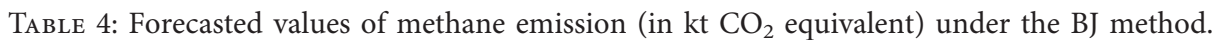

\begin{tabular}{|c|c|c|c|c|c|}
\hline & OECD & Upper middle & Middle & Lower middle & Low \\
\hline \multicolumn{6}{|l|}{1981} \\
\hline \multicolumn{6}{|l|}{1982} \\
\hline 1983 & & & & & 319376.7 \\
\hline 1984 & & & & & 310579.6 \\
\hline 1985 & & & & & 310981.8 \\
\hline 1986 & 1473936 & & & 1441004.78 & 315518.4 \\
\hline 1987 & 1465419 & & & 1417409.14 & 321913 \\
\hline 1988 & 1463133 & & 4266117 & 1382263.046 & 329142.6 \\
\hline 1989 & 1463101 & & 4550070 & 1680835.125 & 336747.6 \\
\hline 1990 & 1465166 & & 4698743 & 1687975.219 & 344521.2 \\
\hline 1991 & 1455061 & & 4460547 & 1673579.499 & 352370.6 \\
\hline 1992 & 1448460 & & 4829691 & 1652224.65 & 360254.1 \\
\hline 1993 & 1443127 & 2830813.3 & 4863760 & 1831934.421 & 368152.9 \\
\hline 1994 & 1438973 & 2787721.237 & 5018868 & 1836056.927 & 376058.5 \\
\hline 1995 & 1427974 & 2797124.06 & 4949627 & 1827204.142 & 383967.3 \\
\hline 1996 & 1418946 & 2850067.461 & 4958414 & 1814158.494 & 391877.4 \\
\hline 1997 & 1410631 & 2799034.691 & 5190341 & 1922253.931 & 399788.2 \\
\hline 1998 & 1402980 & 2896911.307 & 5071963 & 1924558.345 & 407699.3 \\
\hline 1999 & 1391478 & 2774651.862 & 5146852 & 1919045.169 & 415610.4 \\
\hline 2000 & 1381085 & 2794509.994 & 5151927 & 1911005.8 & 423521.7 \\
\hline 2001 & 1371093 & 2846196.11 & 5286403 & 1975953.725 & 431432.9 \\
\hline 2002 & 1361474 & 2937763.268 & 5375874 & 1977162.742 & 439344.2 \\
\hline 2003 & 1349690 & 3074577.474 & 5336641 & 1973661.674 & 447255.5 \\
\hline 2004 & 1338529 & 3156682.078 & 5499459 & 1968638.58 & 455166.7 \\
\hline 2005 & 1327594 & 3287526.848 & 5550803 & 2007590.204 & 463078 \\
\hline 2006 & 1316868 & 3376330.859 & 5642415 & 2008139.246 & 470989.3 \\
\hline 2007 & 1304925 & 3430265.209 & 5659390 & 2005850.47 & 478900.6 \\
\hline 2008 & 1293332 & 3567469.328 & 5702324 & 2002644.676 & 486811.8 \\
\hline 2009 & 1281866 & 3585418.719 & 5819492 & 2025933.573 & 494723.1 \\
\hline 2010 & 1270519 & 3779665.03 & 5820120 & 2026084.981 & 502634.4 \\
\hline 2011 & 1258486 & 3860095.861 & 5885045 & 2024526.609 & 510545.7 \\
\hline 2012 & 1246650 & 3915037.114 & 5926743 & 2022415.735 & 518457 \\
\hline 2013 & 1234886 & 3938039.461 & 6011491 & 2036267.867 & 526368.2 \\
\hline 2014 & 1223188 & 3924805.514 & 6081267 & 2036179.702 & 534279.5 \\
\hline 2015 & 1211105 & 3955385.988 & 6108225 & 2035061.397 & 542190.8 \\
\hline 2016 & 1199133 & 3946932.689 & 6202402 & 2033610.21 & 550102.1 \\
\hline 2017 & 1187201 & 3972147.914 & 6259494 & 2041776.707 & 558013.4 \\
\hline 2018 & 1175306 & 4025288.658 & 6329982 & 2041544.199 & 565924.6 \\
\hline 2019 & 1163195 & 4011742.447 & 6375639 & 2040691.033 & 573835.9 \\
\hline 2020 & 1151146 & 4093701.903 & 6429933 & 2039637.307 & 581747.2 \\
\hline 2021 & 1139119 & 4034473.204 & 6508923 & 2044378.219 & 589658.5 \\
\hline 2022 & 1127114 & 4066394.126 & 6549142 & 2044058.745 & 597569.7 \\
\hline 2023 & 1114986 & 4118728.489 & 6610752 & 2043365.326 & 605481 \\
\hline 2024 & 1102894 & 4196641.262 & 6664634 & 2042551.069 & 613392.3 \\
\hline 2025 & 1090815 & 4303574.03 & 6732839 & 2045228.071 & 621303.6 \\
\hline 2026 & 1078747 & 4375417.828 & 6796062 & 2044856.2 & 629214.9 \\
\hline 2027 & 1066611 & 4478521.992 & 6845041 & 2044259.028 & 637126.1 \\
\hline 2028 & 1054494 & 4554662.573 & 6916382 & 2043589.051 & 645037.4 \\
\hline 2029 & 1042385 & 4608438.88 & 6975386 & 2045022.552 & 652948.7 \\
\hline 2030 & 1030282 & 4715621.726 & 7038846 & 2044619.112 & 660860 \\
\hline$\%$ change from 2012 to 2030 & -17.35 & 20.44 & 18.76 & 1.09 & 27.12 \\
\hline
\end{tabular}

further indicates that the methane emission is sustainable as it does not outweigh the agricultural output. But for the ANN-based results, the significant mean differences are observed for the OECD, upper middle-, and lower middleincome groups which further justify the sustainability of methane emission. The insignificant mean difference results for the middle-income and low-income groups may reveal unsustainable methane emission.

\section{Discussion}

As mentioned, we have attempted to make forecasting of methane emissions and agricultural value added by BJ and ANN methods and tested sustainability of such emissions vis-à-vis agricultural output for the major economic groups of the world for the time up to 2030. The results for methane emissions are seen to be declining for the OECD group but 
TABLE 5: Forecasted values of agriculture output in current USD under the BJ method.

\begin{tabular}{|c|c|c|c|c|c|}
\hline & OECD & Upper middle & Middle & Lower middle & Low \\
\hline \multicolumn{6}{|l|}{1981} \\
\hline \multicolumn{6}{|l|}{1982} \\
\hline 1983 & & & & & 28655746373 \\
\hline 1984 & 77710044855.35 & & & & 29759868468 \\
\hline 1985 & 103315311309.63 & & 474777328761 & 182501651690 & 31221206784 \\
\hline 1986 & 124158617455.24 & 316887909136 & 492678373529 & 193724524521 & 33023207815 \\
\hline 1987 & 131795851566.40 & 334580909413 & 517772413129 & 203354127983 & 35150085147 \\
\hline 1988 & 97528609223.83 & 361108747377 & 538001902142 & 217447785160 & 37586783918 \\
\hline 1989 & 68023008719.08 & 382302596062 & 564857171441 & 234100060898 & 40318946909 \\
\hline 1990 & 139766033659.17 & 407106383042 & 597538283103 & 249778723353 & 43332882220 \\
\hline 1991 & 182368403567.55 & 432417981365 & 626279435743 & 268185274811 & 46615532438 \\
\hline 1992 & 217062773208.99 & 463657882375 & 660387025088 & 288155344067 & 50154445234 \\
\hline 1993 & 172272259627.83 & 491318600145 & 699213155183 & 307530458795 & 53937745323 \\
\hline 1994 & 235427769172.55 & 521401638240 & 734848183280 & 328572528916 & 57954107726 \\
\hline 1995 & 334466976074.37 & 551825425022 & 774829664423 & 350570031761 & 62192732266 \\
\hline 1996 & 334106517412.40 & 586227187857 & 818632846435 & 372203970453 & 66643319249 \\
\hline 1997 & 316890720440.52 & 618227267450 & 859851450306 & 394856550400 & 71296046272 \\
\hline 1998 & 346365067304.62 & 651852758691 & 904590389013 & 418092975119 & 76141546106 \\
\hline 1999 & 383756726220.32 & 685706897185 & 952424648563 & 441107233457 & 81170885600 \\
\hline 2000 & 399217028334.57 & 722230314612 & 998165573532 & 464743961966 & 86375545571 \\
\hline 2001 & 410958400044.11 & 757142168169 & 1046757733111 & 488737465692 & 91747401615 \\
\hline 2002 & 433001397999.27 & 793144696233 & 1097856894532 & 512595208232 & 97278705817 \\
\hline 2003 & 456791256917.46 & 829300649879 & 1147260595639 & 536833329154 & 102962069301 \\
\hline 2004 & 475742222179.18 & 867247727939 & 1198973605145 & 561289467882 & 108790445594 \\
\hline 2005 & 493872649573.26 & 904113423550 & 1252717117643 & 585662645814 & 114757114761 \\
\hline 2006 & 514276008566.72 & 941710977384 & 1305087421241 & 610268264947 & 120855668267 \\
\hline 2007 & 535064791704.67 & 979411481982 & 1359328109431 & 635007110158 & 127079994554 \\
\hline 2008 & 554785930372.17 & 1018313856727 & 1415213368572 & 659695259779 & 133424265273 \\
\hline 2009 & 574326027095.09 & 1056490608353 & 1469986420799 & 684525449312 & 139882922163 \\
\hline 2010 & 594367619206.43 & 1095158447334 & 1526274358835 & 709437050489 & 146450664536 \\
\hline 2011 & 614494250582.09 & 1133895367753 & 1583894288807 & 734317672661 & 153122437337 \\
\hline 2012 & 634385318873.25 & 1173438760262 & 1640613405931 & 759285092425 & 159893419766 \\
\hline 2013 & 654236442407.45 & 1212495249261 & 1698559478743 & 784302261127 & 166759014418 \\
\hline 2014 & 674198214948.72 & 1251881264912 & 1757584375498 & 809300499212 & 173714836936 \\
\hline 2015 & 694178750394.64 & 1291313635198 & 1815879674392 & 834351777473 & 180756706132 \\
\hline 2016 & 714107311641.00 & 1331287159814 & 1875168724927 & 859433456261 & 187880634578 \\
\hline 2017 & 734027059550.69 & 1370933965196 & 1935331550347 & 884503566948 & 195082819625 \\
\hline 2018 & 753971220850.90 & 1410801887684 & 1994903450537 & 909606089367 & 202359634838 \\
\hline 2019 & 773919521963.40 & 1450700914796 & 2055280222764 & 934727188907 & 209707621832 \\
\hline 2020 & 793856355585.46 & 1490963064218 & 2116364693922 & 959841219424 & 217123482486 \\
\hline 2021 & 813791244649.35 & 1531005980352 & 2176970555359 & 984975056067 & 224604071515 \\
\hline 2022 & 833731520238.19 & 1571197269233 & 2238228309050 & 1010120244795 & 232146389386 \\
\hline 2023 & 853672709227.49 & 1611409429763 & 2300059251309 & 1035261113794 & 239747575567 \\
\hline 2024 & 873611368051.09 & 1651865250565 & 2361502551863 & 1060414085898 & 247404902082 \\
\hline 2025 & 893549597831.00 & 1692173962690 & 2423473841329 & 1085573995021 & 255115767372 \\
\hline 2026 & 913489016083.73 & 1732582235055 & 2485909375009 & 1110731264449 & 262877690434 \\
\hline 2027 & 933428635867.43 & 1773004512594 & 2548030944962 & 1135895929829 & 270688305235 \\
\hline 2028 & 953367697400.09 & 1813590289668 & 2610580150446 & 1161064834276 & 278545355386 \\
\hline 2029 & 973306664269.36 & 1854077354712 & 2673505362542 & 1186232125660 & 286446689058 \\
\hline 2030 & 993245893361.05 & 1894631226103 & 2736176285121 & 1211403936555 & 294390254141 \\
\hline$\%$ change from 2012 to 2030 & 56.56 & 61.45 & 66.77 & 56.24 & 79.14 \\
\hline
\end{tabular}

increasing for the remaining four groups. Referring to last row of Table 4 of the Appendix, the OECD group is expected to reduce the emission by 17.35 percent in 2030 in comparison to its value in 2012 . The low-income group is expected to increase their emission levels by 27.12 percent, upper middle-income group by 20.44 percent, and middle income by 18.76 percent, and the lower middle-income group will face lowest emission of mere one percent. The predictions of OECDEO (2011) and USEIA (2016) are a little bit higher (30 percent) than that of the present study $[24,40]$.

Coming to the prediction of agricultural output, it is observed that all the groups have been showing increasing trends with the middle-income group at top of the list and the low-income group at the bottom with respect to the level values. Referring to Table 5 of the Appendix (last row), it is observed that the low-income group is expected to grow at 


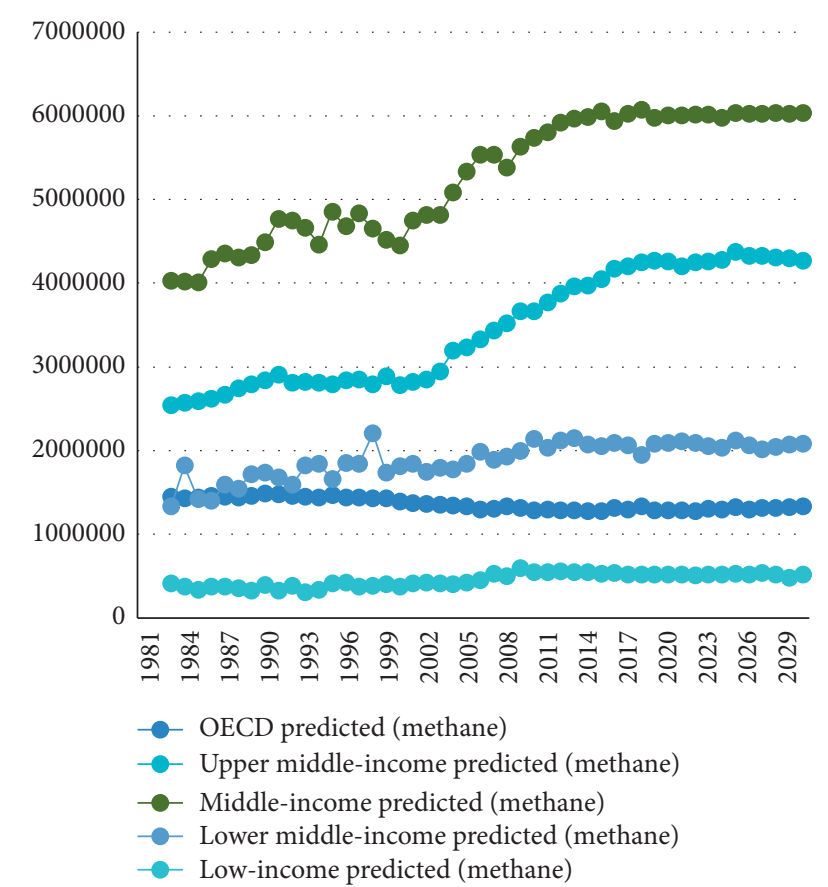

FIgURE 4: Forecasted methane emission by the ANN method. Source: sketched by the authors.

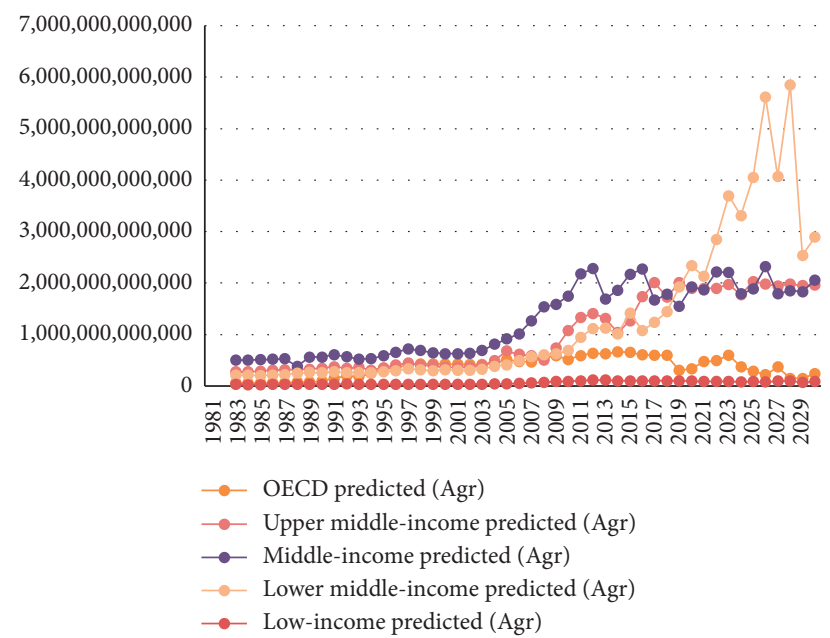

FIGURE 5: Forecasted agriculture output by the ANN method. Source: sketched by the authors.

the rate of 79 percent, middle group by 66.77 percent, upper middle by 61.45 percent, and OECD and lower middle group by 56.56 in 2030 with respect to 2012 . All the results of forecasting are derived under the condition that all the associated indicators to methane emission will behave in the same manner in all the future period of prediction.

The sustainability of the methane emissions has been checked by the mean difference tests between the growth rates of the forecasted values of agricultural output and methane emissions. The results are positive and significant under the BJ method for all the groups which mean that the forecasted values of agriculture output are significantly
TABLE 6: Forecasted values of methane emission (in $\mathrm{kt} \mathrm{CO}_{2}$ equivalent) under the ANN method.

\begin{tabular}{|c|c|c|c|c|c|}
\hline & OECD & $\begin{array}{l}\text { Upper } \\
\text { middle }\end{array}$ & vilade & $\begin{array}{l}\text { Lower } \\
\text { middle }\end{array}$ & Low \\
\hline \multicolumn{6}{|l|}{1981} \\
\hline \multicolumn{6}{|l|}{1982} \\
\hline 1983 & 1446416.968 & 2545150 & 4026870 & 1329748 & 412875 \\
\hline 1984 & 1430021.447 & 2571500 & & & \\
\hline 1985 & $14417 \mathrm{~S}$ & 589046 & & 22605 & \\
\hline 1986 & 1461538.199 & 2614282 & & & \\
\hline 1987 & 1446995.651 & 2667094 & & 588817 & 373211 \\
\hline 1988 & 144 & 20 & & & \\
\hline 1989 & 1456140 & 792646 & & & \\
\hline 1990 & 14913 & 51 & & & \\
\hline 1991 & 1476 & 15 & & & \\
\hline 1992 & & & & & \\
\hline 1993 & 144 & & & & \\
\hline 1994 & 1 & & & & \\
\hline 1995 & 146 & & & & \\
\hline 1996 & & & & & \\
\hline 97 & 1 & & & & \\
\hline 1998 & 143 & & & & \\
\hline 1999 & 142 & 1 & & & \\
\hline 2000 & & & & & \\
\hline 2001 & & & & & \\
\hline 2002 & 1366 & 0 & & & \\
\hline 2003 & 135 & & & & \\
\hline 2004 & 134 & & & & \\
\hline 2005 & 133 & & & & \\
\hline 2006 & 1297 & 4 & & & 54203 \\
\hline 2007 & 130 & & & & \\
\hline & & & & & \\
\hline 2009 & & & & & \\
\hline 2010 & 128 & & & & \\
\hline 2011 & & & & & \\
\hline & & & & & \\
\hline 2013 & 128 & & & & 48 \\
\hline 2014 & 1278 & & & & \\
\hline & & & & & \\
\hline & & & & & \\
\hline 2017 & 129 & 4 & 9 & 35 & 451 \\
\hline 2018 & & 4249025 & & & 516794 \\
\hline 2019 & 12809 & & & & \\
\hline 2020 & 1284 & 426 & & 2088 & \\
\hline 2021 & 1281190.139 & 4204223 & 6 & 27 & 515246 \\
\hline 2022 & 1274927.663 & 4249874 & 6010389 & 2089217 & 511396 \\
\hline 2023 & 1303026.248 & 4263496 & & 2056467 & \\
\hline 2024 & 1293 & & & & \\
\hline 2025 & 1319416.3 & 4375672 & 6033272 & 2117189 & 526181 \\
\hline 2026 & 12963 & 4329229 & 6028447 & 2064709 & 522406 \\
\hline 2027 & 1311785.835 & 4324037 & 6024229 & 2013127 & 540581 \\
\hline 2028 & & & & & 519592 \\
\hline 2029 & 1324572.071 & 4294304 & 6024831 & 2074644 & 481711 \\
\hline 2030 & 1335745.338 & 4265628 & 6029050 & 2084001 & 514628 \\
\hline
\end{tabular}

greater than that of methane emission. This further indicates that the methane emission is sustainable as it does not outweigh the agricultural output. But for the ANN-based results, the significant mean differences are observed for the OECD, upper middle-, and lower middle-income groups which further justify the sustainability of methane emission. Hence, it is recommended that, considering all the other 
TABLE 7: Forecasted values of agriculture output in current USD under the ANN method.

\begin{tabular}{|c|c|c|c|c|c|}
\hline & OECD & Upper middle & Middle & Lower middle & Low \\
\hline \multirow{2}{*}{\multicolumn{6}{|c|}{$\begin{array}{l}1981 \\
1982\end{array}$}} \\
\hline & & & & & \\
\hline 1983 & 60149562148 & 275816000000 & 501816000000 & 208478000000 & 27914162124 \\
\hline 1984 & 58623413411 & 273072000000 & 505240000000 & 208728000000 & 26378101124 \\
\hline 1985 & 58512134674 & 289552000000 & 511902000000 & 205128000000 & 23808297707 \\
\hline 1986 & 58687934646 & 305404000000 & 519899000000 & 211354000000 & 28931592469 \\
\hline 1987 & 64737081234 & 317137000000 & 530667000000 & 220927000000 & 31653039004 \\
\hline 1988 & 75454827282 & 317232000000 & 381891000000 & 245092000000 & 32486810073 \\
\hline 1989 & 78636358047 & 325654000000 & 563200000000 & 264922000000 & 34863281281 \\
\hline 1990 & 97586011959 & 345238000000 & 560167000000 & 255171000000 & 33617076366 \\
\hline 1991 & 148770000000 & 374179000000 & 608340000000 & 274660000000 & 35340660729 \\
\hline 1992 & 195534000000 & 345860000000 & 564271000000 & 258976000000 & 39010629608 \\
\hline 1993 & 180284000000 & 360263000000 & 522557000000 & 259832000000 & 35238321276 \\
\hline 1994 & 245800000000 & 309740000000 & 526438000000 & 253594000000 & 35270050041 \\
\hline 1995 & 340404000000 & 356072000000 & 587710000000 & 272472000000 & 29869388592 \\
\hline 1996 & 348603000000 & 408722000000 & 650495000000 & 296111000000 & 33179564625 \\
\hline 1997 & 411922000000 & 446542000000 & 722873000000 & 329157000000 & 35083613270 \\
\hline 1998 & 428733000000 & 405384000000 & 687618000000 & 318122000000 & 36849209370 \\
\hline 1999 & 432306000000 & 398112000000 & 647510000000 & 292989000000 & 35432666001 \\
\hline 2000 & 427107000000 & 357321000000 & 625239000000 & 317995000000 & 33687746404 \\
\hline 2001 & 423704000000 & 363411000000 & 627118000000 & 304337000000 & 37074676523 \\
\hline 2002 & 415854000000 & 368313000000 & 636532000000 & 307672000000 & 33399273994 \\
\hline 2003 & 414608000000 & 398710000000 & 688031000000 & 327384000000 & 34299616147 \\
\hline 2004 & 443383000000 & 496823000000 & 809029000000 & 384573000000 & 37145185371 \\
\hline 2005 & 508433000000 & 677856000000 & 915925000000 & 409008000000 & 40513455887 \\
\hline 2006 & 478442000000 & 612859000000 & 1014990000000 & 490946000000 & 54159541508 \\
\hline 2007 & 468780000000 & 588534000000 & 1265260000000 & 569372000000 & 60077425963 \\
\hline 2008 & 548197000000 & 501164000000 & 1534920000000 & 605306000000 & 70586165066 \\
\hline 2009 & 586888000000 & 739111000000 & 1587530000000 & 625364000000 & 85904323805 \\
\hline 2010 & 513235000000 & 1078720000000 & 1745390000000 & 687756000000 & 90543840883 \\
\hline 2011 & 591661000000 & 1329470000000 & 2174670000000 & 947791000000 & 98291166756 \\
\hline 2012 & 636341000000 & 1410410000000 & 2285030000000 & 1119160000000 & 113311000000 \\
\hline 2013 & 623553000000 & 1316770000000 & 1689750000000 & 1125900000000 & 113776000000 \\
\hline 2014 & 661119000000 & 1037670000000 & 1862420000000 & 1011140000000 & 100679000000 \\
\hline 2015 & 655130000000 & 1266020000000 & 2170550000000 & 1416910000000 & 100257000000 \\
\hline 2016 & 605669000000 & 1733390000000 & 2271590000000 & 1073130000000 & 100800000000 \\
\hline 2017 & 600843000000 & 2007280000000 & 1667260000000 & 1238350000000 & 100759000000 \\
\hline 2018 & 592490000000 & 1728370000000 & 1779174000000 & 1440630000000 & 100237000000 \\
\hline 2019 & 303534000000 & 2006880000000 & 1550970000000 & 1921060000000 & 102262000000 \\
\hline 2020 & 337184000000 & 1896250000000 & 1923180000000 & 2335620000000 & 93900354646 \\
\hline 2021 & 472782000000 & 1897960000000 & 1868950000000 & 2128200000000 & 86932691913 \\
\hline 2022 & 490161000000 & 1896060000000 & 2212620000000 & 2850170000000 & 92594909122 \\
\hline 2023 & 599283000000 & 1974230000000 & 2208870000000 & 3696460000000 & 87350971903 \\
\hline 2024 & 374703000000 & 1770710000000 & 1788500000000 & 3307450000000 & 80836950006 \\
\hline 2025 & 290853369722 & 2030700000000 & 1883096000000 & 4048230000000 & 85262451407 \\
\hline 2026 & 217660000000 & 1983130000000 & 2314470000000 & 5614650000000 & 78306777946 \\
\hline 2027 & 367982000000 & 1941340000000 & 1789040000000 & 4069740000000 & 94908000000 \\
\hline 2028 & 145581000000 & 1984130000000 & 1849430000000 & 5847880000000 & 96808438305 \\
\hline 2029 & 147648000000 & 1948150000000 & 1833780000000 & 2539530000000 & 72947073894 \\
\hline 2030 & 235620957663 & 1962620000000 & 2053360000000 & 2888470000000 & 88625925490 \\
\hline
\end{tabular}


TABLE 8: Mean difference test results.

\begin{tabular}{lccccccccc}
\hline & \multicolumn{3}{c}{ Mean difference under BJ method } & \multicolumn{3}{c}{ Mean difference under ANN method } \\
Groups & $\begin{array}{c}\text { Mean } \\
\text { (agri) }\end{array}$ & $\begin{array}{c}\text { Mean } \\
\text { (methane) }\end{array}$ & $\begin{array}{c}\text { Corr. } \\
\text { coefficient }\end{array}$ & $\begin{array}{c}t \\
\text { (agri-methane) }\end{array}$ & $\begin{array}{c}\text { Mean } \\
\text { (agri) }\end{array}$ & $\begin{array}{c}\text { Mean } \\
\text { (methane) }\end{array}$ & $\begin{array}{c}\text { Corr. } \\
\text { coefficient }\end{array}$ & $\begin{array}{c}t \\
\text { (agri-methane) }\end{array}$ \\
\hline $\begin{array}{l}\text { OECD } \\
\text { Upper }\end{array}$ & 0.05539 & -0.00813 & $\mathbf{- 0 . 9 8}$ & $\mathbf{2 . 7 0}$ & 5.945 & -0.1584 & 0.29 & $\mathbf{1 . 7 4}$ \\
middle & 0.04064 & 0.01379 & $\mathbf{0 . 9 7}$ & $\mathbf{7 . 4 0}$ & 5.264 & 1.125 & 0.38 & $\mathbf{1 . 8 5}$ \\
Middle & 0.03892 & 0.0119 & $\mathbf{0 . 9 9}$ & $\mathbf{1 7 . 0 6}$ & 4.085 & 0.904 & 0.175 & 1.46 \\
Lower & 0.0420 & 0.0079 & $\mathbf{0 . 7 8}$ & $\mathbf{2 4 . 1 2}$ & 7.578 & 1.345 & -0.003 & $\mathbf{2 . 0 6}$ \\
middle & 0.0495 & 0.0154 & $\mathbf{0 . 9 9}$ & $\mathbf{2 8 . 9 4}$ & 3.075 & 0.838 & 0.28 & 1.08 \\
Low & & &
\end{tabular}

Note. Bold marks indicate significant results at $5 \%$ level. Source: authors' calculations.

factors of forecasting to be unchanged for the forecasting period, sustained agricultural activities may be a better solution which will be viable in economic as well as environmental fronts.

\section{Conclusion}

In our journey to forecast methane emission and agricultural output of world's leading groups by two methods, $\mathrm{BJ}$ and ANN, it is now to conclude the entire study. Both the methods of forecasting show that, except the OECD group, all the four remaining groups display increasing methane emission, but agricultural output is of increasing trends for all. Middle-income countries possess the top slot in both the methods. So, increase in methane emission is an alarming issue to the global leaders for the sake of environmental sustainability. Furthermore, testing for sustainability of such increasing emission vis-à-vis agricultural output, it is observed that the said emission is sustainable since the average growth rate of the latter is greater than that of the former. Hence, the environmental damage in true sense through methane emission may not be alarming as it boosts up the agricultural growth rate for all the groups. But the effect of methane emission upon other sectors of the economies for examining sustainability in a broader sense remains unverified. It may be kept as the agenda for future research.

\section{Conflicts of Interest}

The authors declare that they have no conflicts of interest.

\section{References}

[1] B. Herrendorf, R. Rogerson, and A. Valentinyi, Growth and Structural Transformation. NBER Working Paper No. 18996, National Bureau of Economic Research, Cambridge, MA, USA, 2013.

[2] S. Kuznets, "Modern economic growth: findings and Reflections," The American Economic Review, vol. 63, pp. 247258, 1973.

[3] B. R. Copeland and M. S. Taylor, "Trade, growth, and the environment," Journal of Economic Literature, vol. 42, no. 1, pp. 7-71, 2004.

[4] O. Fernández-Amador, J. F. Francois, D. A. Oberdabernig, and $\mathrm{P}$. Tomberger, "Economic growth, sectoral structures, and environmental methane footprints," Applied Economics, vol. 52, no. 13, p. 1460, 2019.

[5] O. Fernández-Amador, J. F. Francois, D. A. Oberdabernig, and P. Tomberger, "Carbon dioxide emissions and economic growth: an assessment based on production and consumption emission inventories," Ecological Economics, vol. 135, pp. 269-279, 2017.

[6] FOA, Estimating Greenhouse Gas Emissions in Agriculture: A Manual to Address Data Requirements for Developing Countries, Food and Agriculture Organization of the United Nations Rome, Rome, Italy, 2015, http://www.fao.org/3/ai4260e.pdf.

[7] IPCC, Climate Change 2014: Synthesis Report. Contribution of Working Groups I, II, and III to the Fifth Assessment Report of the Intergovernmental Panel on Climate Change, IPCC, Geneva, Switzerland, 2014.

[8] IPCC, "Good practice guidance and uncertainty management in national greenhouse gas inventories," in IPCC National Greenhouse Gas Inventories Programme, Technical Support Unit, J. Penman, Ed., IPCC, Geneva, Switzerland, 2000.

[9] IPCC, Climate Change 1995-the Science of Climate Change: Contribution of Working Group I to the Second Assessment Report of the Intergovernmental Panel on Climate Change, Cambridge University Press, Cambridge, UK, 1996.

[10] IPCC, IPCC Guidelines for National Greenhouse Gas Inventories: Glossary, Japan, IPCC, Geneva, Switzerland, 2006, http://www.ipccnggip.iges.or.jp/public/gpglulucf/ gpglulucf_files/Glossary_Acronyms_BasicInfo/Glossary. pdf.

[11] O. Fernández-Amador, J. F. Francois, D. A. Oberdabernig, and P. Tomberger, The Methane Footprint of Nations: Evidence from Global Panel Data, World Trade Institute, University of Bern, Bern, Switzerland, 2018.

[12] Global Methane Initiative, Agricultural Methane: Reducing Emissions, Advancing Recovery and Use Opportunities, Global Methane Initiative, Washington, DC, USA, 2011, http://www. globalmethane.org.

[13] C. Hope, "Discount rates, equity weights and the social cost of carbon," Energy Economics, vol. 30, no. 3, pp. 1011-1019, 2008.

[14] B. M. Haddad, "Ranking the adaptive capacity of nations to climate change when socio-political goals are explicit," Global Environmental Change, vol. 15, no. 2, pp. 165-176, 2005.

[15] UNISDR, Sendai Framework for Disaster Risk Reduction 2015-2030, UNISDR, Geneva, Switzerland, 2015, http://www. unisdr.org.

[16] A. Acaravci and I. Ozturk, "On the relationship between energy consumption, $\mathrm{CO}_{2}$ emissions and economic growth in Europe," Energy, vol. 35, no. 12, pp. 5412-5420, 2010. 
[17] N. Apergis and I. Ozturk, "Testing environmental Kuznets curve hypothesis in Asian countries," Ecological Indicators, vol. 52, pp. 16-22, 2015.

[18] D. Coondoo and S. Dinda, "Causality between income and emission: a country group-specific econometric analysis," Ecological Economics, vol. 40, no. 3, pp. 351-367, 2002.

[19] A. Kasman and Y. S. Duman, " $\mathrm{CO}_{2}$ emissions, economic growth, energy consumption, trade and urbanization in new EU member and candidate countries: a panel data analysis," Economic Modelling, vol. 44, pp. 97-103, 2015.

[20] C.-H. Cho, Y.-P. Chu, and H.-Y. Yang, "An environment Kuznets curve for GHG emissions: a panel cointegration analysis," Energy Sources, Part B: Economics, Planning, and Policy, vol. 9, no. 2, pp. 120-129, 2014.

[21] H. Fujii and S. Managi, "Economic development and multiple air pollutant emissions from the industrial sector," Environmental Science and Pollution Research, vol. 23, no. 3, pp. 2802-2812, 2016.

[22] J. Kubicová, "Testing greenhouse gasses in Slovakia for environmental Kuznets curve and pollution haven hypothesis," Journal of International Studies, vol. 7, no. 2, pp. 161-177, 2014.

[23] V. Marchal, R. Dellink, D. van Vuuren et al., OECD Environmental Outlook to 2050, OECD, Paris, France, 2011.

[24] OECDEO, OECD Environmental Outlook to 2030, OECDEO, Paris, France, 2008, https://www.oecd.org/env/indicatorsmodelling-outlooks/40200582.pdf.

[25] W. Ali and A. Abdullah, "The long-run relationship between economic growth, financial development, trade openness and $\mathrm{CO}_{2}$ emissions in Malaysia," in Proceedings of the 2nd International Symposium on Technology Management and Emerging Technologies, ISTMET 2015, pp. 309-313, Langkawi, Malaysia, August 2015.

[26] M. Benavides, K. Ovalle, C. Torres, and T. Vinces, "Economic growth, renewable energy and methane emissions: is there an enviromental kuznets curve in Austria?" International Journal of Energy Economics and Policy, vol. 7, no. 1, pp. 259-267, 2017.

[27] M. Du, Q. Zhu, X. Wang et al., "Estimates and predictions of methane emissions from wastewater in China from 2000 to 2020," Earth's Future, vol. 6, no. 2, pp. 252-263, 2018.

[28] O. Fernández-Amador, J. F. Francois, D. A. Oberdabernig, and P. Tomberger, "Empirical estimates of the methane-income elasticity," Economics Letters, vol. 171, pp. 137-139, 2018.

[29] M. Shahbaz, S. Dube, I. Ozturk, and A. Jalil, "Testing the environmental Kuznets curve hypothesis in Portugal," International Journal of Energy Economics and Policy, vol. 5, no. 2, pp. 475-481, 2015.

[30] M. Shahbaz, N. Khraief, G. S. Uddin, and I. Ozturk, "Environmental Kuznets curve in an open economy: a bounds testing and causality analysis for Tunisia," Renewable and Sustainable Energy Reviews, vol. 34, pp. 325-336, 2014.

[31] J. Bates, "Economic evaluation of sectoral emission reduction objectives for climate change: economic evaluation of emission reductions of nitrous oxides and methane in agriculture in the eu bottom-up analysis," ATAT Environment, Final Report (Updated Version), 2001.

[32] T. Hasegawa and Y. Matsuoka, "Global methane and nitrous oxide emissions and reduction potentials in agriculture," Journal of Integrative Environmental Sciences, vol. 7, no. sup1, pp. 245-256, 2010.
[33] W. N. Adger, N. Arnett, and E. Tompkins, "Successful adaptation to climate change across scales," Global Environmental Change, vol. 15, pp. 77-86, 2005.

[34] S. Asghar, D. Alahakoon, and L. Churilov, A Comprehensive Conceptual Model for Disaster Management, Clayton School of Information Technology, Monash University, Melbourne, Australia, 2006.

[35] J. Barnett and S. O'Neill, "Maladaptation," Global Environmental Change, vol. 20, no. 2, pp. 211-213, 2010.

[36] M. K. Maredia and I. J. Minde, "Technology profitability and agricultural transformation: concepts, evidence and policy implications," in Perspectives on Agricultural Transformation: A View from Africa, T. S. Jayne, P. Minde, and G. G. Argwings-Kodhek, Eds., pp. 83-116, Nova Science Publishers Inc., New York, NY, USA, 2002.

[37] N. Mimura, R. S. Palwarty, D. M. Duc et al., "Adaptation planning and implementation," in Climate Change: Impacts, Adaptation and Vulnerability. Part A. Global and Sectoral Aspects. Contribution of Working Group II to the Fifth Assessment Report of IPCC, 869-898, C. B. Field, Ed., Cambridge University Press, Cambridge, UK, 2014.

[38] T. E. Volenzo, Alternative dairy cattle feeding strategies and climate change risk management in the maize-sugarcane Belt, Western Kenya, PhD Thesis, Masinde Muliro University of Science and Technology, Kakamega, Kenya, 2015.

[39] T. E. Volenzo, J. O. Odiyo, and J. Obiri, "Greenhouse gas emissions as sustainability indicators in agricultural sectors' adaptation to climate change: policy implications," Jàmbá: Journal of Disaster Risk Studies, vol. 11, no. 1, 2019.

[40] USEIA, United States Energy Information AdministrationUSEIA, 2016, https://www.eia.gov/ todayinenergy/detail.php?id=26252.

[41] USEPA, Global Mitigation of non-CO2 Greenhouse Gases, U.S. Environmental Protection Agency, Washington, DC, USA, 2006.

[42] M. Kurian and K. Meyer, "The UNU-FLORES United Nations University Institute for Integrated Management of material fluxes and resources nexus observatory and the post 2015 monitoring agenda," 2015, https://sustainabledevelopment. un.org/content/documents/6614131-Kurian-The\%20 UNUFLORES\%20Nexus\%20Observatory\%20and\%20the\%20Post\%202015\%20 Monitoring\%20Agenda.pdf.

[43] Q. Cao, B. T. Ewing, and M. A. Thompson, "Forecasting wind speed with recurrent neural networks," European Journal of Operational Research, vol. 221, no. 1, pp. 148154, 2012.

[44] M. Ibrahim, S. Jemei, G. Wimmer, and D. Hissel, "Nonlinear autoregressive neural network in an energy management strategy for battery/ultra-capacitor hybrid electrical vehicles," Electric Power Systems Research, vol. 136, pp. 262-269, 2016.

[45] Y. D. Nyanteh, S. K. Srivastava, C. S. Edrington, and D. A. Cartes, "Application of artificial intelligence to stator winding fault diagnosis in Permanent Magnet Synchronous Machinesficial intelligence to stator winding fault diagnosis in Permanent Magnet Synchronous Machines," Electric Power Systems Research, vol. 103, pp. 201-213, 2013.

[46] M. Alwakeel and Z. Shaaban, "Face Recognition based on haar wavelet transform and principal component analysis via Levenberg-Marquardt backpropagation neural network," European Journal Science Research, vol. 42, pp. 25-31, 2010. 
[47] M. T. Hagan and M. B. Menhaj, "Training feedforward networks with the Marquardt algorithm," IEEE Transactions on Neural Networks, vol. 5, no. 6, pp. 989-993, 1994.

[48] A. A. Adebiyi, A. O. Adewumi, and C. K. Ayo, "Comparison of ARIMA and artificial neural networks models for stock price prediction," Journal of Applied Mathematics, vol. 2014, Article ID 614342, 7 pages, 2014.

[49] Y. Chen, B. Yang, J. Dong, and A. Abraham, "Time-series forecasting using flexible neural tree model," Information Sciences, vol. 174, no. 3-4, pp. 219-235, 2005.

[50] A. Jain and A. M. Kumar, "Hybrid neural network models for hydrologic time series forecasting," Applied Soft Computing, vol. 7, no. 2, pp. 585-592, 2007. 